University of Montana

ScholarWorks at University of Montana

Ecosystem and Conservation Sciences Faculty

Publications

Ecosystem and Conservation Sciences

$6-2015$

\title{
Topographic controls on soil nitrogen availability in a lowland tropical forest
}

\author{
Samantha R. Weintraub \\ University of Utah \\ Philip G. Taylor \\ University of Colorado Boulder \\ Stephen Porder \\ Brown University, Providence, Rhode Island \\ Cory C. Cleveland \\ The University of Montana, cory.cleveland@umontana.edu \\ Gregory P. Asner \\ Carnegie Institution for Science \\ See next page for additional authors
}

Follow this and additional works at: https://scholarworks.umt.edu/decs_pubs

Part of the Ecology and Evolutionary Biology Commons

Let us know how access to this document benefits you.

\section{Recommended Citation}

Samantha R. Weintraub, Philip G. Taylor, Stephen Porder, Cory C. Cleveland, Gregory P. Asner, and Alan R. Townsend 2015. Topographic controls on soil nitrogen availability in a lowland tropical forest. Ecology 96:1561-1574. http://dx.doi.org/10.1890/14-0834.1

This Article is brought to you for free and open access by the Ecosystem and Conservation Sciences at ScholarWorks at University of Montana. It has been accepted for inclusion in Ecosystem and Conservation Sciences Faculty Publications by an authorized administrator of ScholarWorks at University of Montana. For more information, please contact scholarworks@mso.umt.edu. 
Authors

Samantha R. Weintraub, Philip G. Taylor, Stephen Porder, Cory C. Cleveland, Gregory P. Asner, and Alan R. Townsend 


\title{
Topographic controls on soil nitrogen availability in a lowland tropical forest
}

\author{
Samantha R. Weintraub, ${ }^{1,7}$ Philip G. Taylor,${ }^{2}$ Stephen Porder,${ }^{3}$ Cory C. Cleveland, ${ }^{4}$ Gregory P. Asner,${ }^{5}$ \\ and Alan R. TOWnSEnd ${ }^{6}$ \\ ${ }^{1}$ Department of Geology and Geophysics, University of Utah, Salt Lake City, Utah 84112 USA \\ ${ }^{2}$ INSTAAR, University of Colorado, Boulder, Colorado 80303 USA \\ ${ }^{3}$ Department of Ecology and Evolutionary Biology, Brown University, Providence, Rhode Island 02912 USA \\ ${ }^{4}$ Department of Ecosystem and Conservation Sciences, University of Montana, Missoula, Montana 59812 USA \\ ${ }^{5}$ Department of Global Ecology, Carnegie Institution for Science, Stanford, California 94305 USA \\ ${ }^{6}$ Nicholas School of the Environment, Duke University, Durham, North Carolina 27708 USA
}

\begin{abstract}
Geomorphic position often correlates with nutrient cycling across landscapes. In tropical forests, topography is known to influence phosphorus (P) availability, but its effect on nitrogen $(\mathrm{N})$ cycling has received less exploration, especially in lowland forests where widespread $\mathrm{N}$ richness is frequently assumed. Here, we report significant effects of topographic slope and landscape position on multiple aspects of the $\mathrm{N}$ cycle across a highly dissected lowland tropical forest on the Osa Peninsula, Costa Rica. A suite of $\mathrm{N}$ cycle metrics measured along a topographic sequence revealed a distinct gradient in $\mathrm{N}$ availability. Values of soil $\delta^{15} \mathrm{~N}$, inorganic $\mathrm{N}$ pools, net nitrification rates, and nitrification potentials were all substantially lower on a flanking steep hillslope $\left(\sim 28^{\circ}\right)$ compared to a relatively flat ridge top $\left(\sim 6^{\circ}\right)$, indicating lower $\mathrm{N}$ availability and a less open $\mathrm{N}$ cycle in steep parts of the landscape. Slope soils also hosted smaller total carbon and nitrogen stocks and notably less weathered soil minerals than did ridge soils. These latter findings suggest that elevated $\mathrm{N}$ loss resulting from high rates of soil and particulate organic matter erosion could underpin the spatial variation in $\mathrm{N}$ cycling and availability. Expanding our analysis to the larger study landscape, a strong negative linear relationship between soil $\delta^{15} \mathrm{~N}$ values and surface slope angles was observed. $\mathrm{N}$ isotope mass balance models suggest that this pattern is most plausibly explained by an increase in $\mathrm{N}$ loss via erosive, non-fractioning pathways from steep zones, as most other variables commonly assumed to affect soil $\delta^{15} \mathrm{~N}$ values (such as temperature, precipitation, and vegetation type) did not vary across the sampled region. Together, these results reveal notable hillslope-scale variation in $\mathrm{N}$ richness and suggest an important role for nonfractionating $\mathrm{N}$ loss in the maintenance of this pattern. Such findings highlight the importance of geomorphology and the significant capacity of erosion to influence $\mathrm{N}$ availability in steepland ecosystems.
\end{abstract}

Key words: hillslope; nitrogen cycle; nutrient limitation; Osa Peninsula, Costa Rica; soil erosion; tropical forest.

\section{INTRODUCTION}

Tropical forests display notable heterogeneity in nutrient cycling (Cuevas and Medina 1986, Vitousek and Sanford 1986, Laurance et al. 1999, Porder et al. 2005, Nardoto et al. 2008), and nutrient constraints on ecosystem processes vary from local to regional scales even within humid lowland forests (Kaspari et al. 2008, Townsend et al. 2011, Wright et al. 2011, Alvarez-Clare et al. 2013). In large part, such variation is a product of unique and diverse combinations in the state factors that regulate terrestrial ecosystem processes and soil development (i.e., climate, organisms, topography, parent material, time; Jenny 1941, Amundson and Jenny 1997,

Manuscript received 2 May 2014; revised 13 November 2014; accepted 17 November 2014. Corresponding Editor: R. A. Dahlgren.

${ }^{7}$ E-mail: samantha.weintraub@utah.edu
Townsend et al. 2008). This nutrient cycling heterogeneity presents a substantial challenge to predicting ecosystem function across diverse tropical landscapes (Randerson et al. 2009, Cleveland et al. 2011, Townsend et al. 2011). Resolving the drivers and resultant effects of this variation is essential, as tropical forests will play important roles in a host of global environmental change scenarios (Nemani et al. 2003, Clark 2004, Bonan 2008).

Topography is one of the state factors that contributes to landscape-scale variation in tropical nutrient cycling. On short timescales, high rainfall can cause significant hydrologic transport, redistributing nutrients and carbon downslope and along flowpaths (McSwiney et al. 2001, Chaves et al. 2009). On longer timescales, geomorphology regulates nutrient cycling via effects on soil development and residence times (Jenny 1941, Walker and Syers 1976, Tiessen et al. 1994, Birkeland 
1999). For example, in low-gradient forests of the Amazon basin, topographic position can cause large differences in soil development, with quartz sand Spodosols forming in seasonally inundated valleys vs. high-clay Oxisols on upper slopes and ridges. These soil development trends affect nutrient availability and determine spatial patterns of nitrogen (N) vs. phosphorus (P) limitation of forest productivity (Tiessen et al. 1994). Topography has also been shown to affect soil nutrient status in high-gradient landscapes (Porder et al. 2005), but there, physical erosion plays an increasingly important role in spatial patterns of nutrient availability.

Slope gradient is among the central drivers of the rate of physical erosion in soil-mantled landscapes (Heimsath et al. 1997, Roering et al. 1999), and differences in slope-mediated landscape stability create differences in soil residence times across steeply dissected terrain. Thus while humid, low-latitude regions are known for their deep, highly weathered soils that are depleted in primary minerals and nutrients derived from rock weathering (Johnsson and Stallard 1989, Thomas 1994, Buss et al. 2010), the extent of rock-derived nutrient depletion is strongly affected by topography. Particularly where landscape form is still adjusting to changes in erosion regime (Ahnert 1994), steep tropical hillslopes maintain thinner, less weathered soils than nearby ridges and tend to have a higher abundance of elements derived from primary mineral weathering, including $\mathrm{P}$ (Scatena and Lugo 1995, Vitousek et al. 2003, Porder et al. 2007). The rejuvenation of rock-derived nutrients (particularly $\mathrm{P}$ ) by erosion has broad ecological significance because $\mathrm{P}$ limitation is thought to be common in late-successional lowland tropical forests (Vitousek and Sanford 1986, Cleveland et al. 2011).

The physical removal of surface soils from steep slopes can rejuvenate the supply of rock-derived nutrients such as $\mathrm{P}$, but it may also lead to substantial losses of $\mathrm{N}$, as soil $\mathrm{N}$ concentrations are highest at the surface. Mature lowland tropical forests are commonly characterized as $\mathrm{N}$-rich, with an open $\mathrm{N}$ cycle (i.e., large losses of $\mathrm{N}$ from bioavailable pools), as a result of $\mathrm{N}$ accumulation in excess of demand (Vitousek and Matson 1988, Martinelli et al. 1999). There is ample evidence supporting this paradigm (Vitousek and Sanford 1986, Vitousek and Farrington 1997, Hedin et al. 2009), yet much of it is drawn from the study of geomorphologically stable sites with low rates of physical erosion. For wet tropical forests in actively eroding terrain, both nutrient inputs and losses due to erosion may regulate spatial patterns of soil fertility and associated ecosystem functions (Scatena and Lugo 1995, Porder and Hilley 2011), and should thus be considered. Where erosion rates vary across the landscape, the potential exists for significant effects on $\mathrm{N}$ as well as $\mathrm{P}$ cycling, and likely in the opposite direction for the different nutrients. However, effects on $\mathrm{N}$ cycling have been less thoroughly explored, especially in the lowland tropics.

Unlike lithogenic nutrients, which become depleted over time (Walker and Syers 1976), most N enters ecosystems from the atmosphere (though see Holloway and Dahlgren [2002]) and tends to accumulate in surface soils as they age (Jenny 1941, Olff et al. 1993, Chapin et al. 1994, Vitousek 2004). Indeed, the broad paradigm of $\mathrm{N}$-rich, P-poor tropical forest soils rests in part on sufficiently long soil residence times that allow for substantial $\mathrm{N}$ accumulation and concurrent $\mathrm{P}$ depletion via chemical weathering and leaching (Walker and Syers 1976, Crews et al. 1995). However, high rates of erosion of topsoil and detritus from steep slopes may constrain $\mathrm{N}$ accumulation, preventing hillslopes from achieving the typical N-rich state often found in tropical flatlands. At the watershed scale, empirical studies and models point toward high physical erosion losses from mountainous tropical catchments (Shanley et al. 2011, Pelletier 2012, Zimmermann et al. 2012), with potentially large losses of particulate nitrogen as well (Kao and Liu 2000, Townsend-Small et al. 2005; Taylor et al., in press). Recent evidence also suggests that hillslope-scale variation in erosion rates may be linked to local soil $\mathrm{N}$ dynamics. For example, across montane tropical forests in Taiwan and Peru, Hilton et al. (2013) observed declining soil ${ }^{15} \mathrm{~N}$ natural abundance $\left(\delta^{15} \mathrm{~N}\right)$ values with increasing slope angles. By applying ${ }^{15} \mathrm{~N}$ mass balance models to this data, the authors were able to attribute this pattern to increased non-fractionating, erosive $\mathrm{N}$ loss on steeper slopes relative to other N-loss pathways. In a lower-gradient temperate landscape, Amundson et al. (2003) similarly observed a decline in soil $\delta^{15} \mathrm{~N}$ values with an increase in slope angle and invoked higher rates of soil $\mathrm{N}$ erosion and less-open $\mathrm{N}$ cycling (or less $\mathrm{N}$ loss from biologically available pools in favor of biologically unavailable ones) on steeper slopes. These studies suggest that soil $\mathrm{N}$ dynamics may be influenced by local geomorphic processes, yet to date there have been few attempts to assess more broadly whether geomorphology causes ecologically relevant variation in $\mathrm{N}$ availability, especially across dissected lowland forests where widespread $\mathrm{N}$ abundance is often assumed.

In this context, we explored links between topography and $\mathrm{N}$ cycling in a dissected, humid lowland tropical forest in southwest Costa Rica. The study region is characterized by a mixture of forested hillslopes and ridge tops dissected by bedrock streams. We hypothesized that steep slopes would have substantially lower $\mathrm{N}$ availability than the relatively flat, stable ridge tops, and that physical removal of surface soil and organic matter could be invoked to explain lower stocks and flows of $\mathrm{N}$ in steep regions.

\section{Methods \\ Study site}

This study was conducted in a primary lowland tropical forest at the Rio Piro Research Station on the 

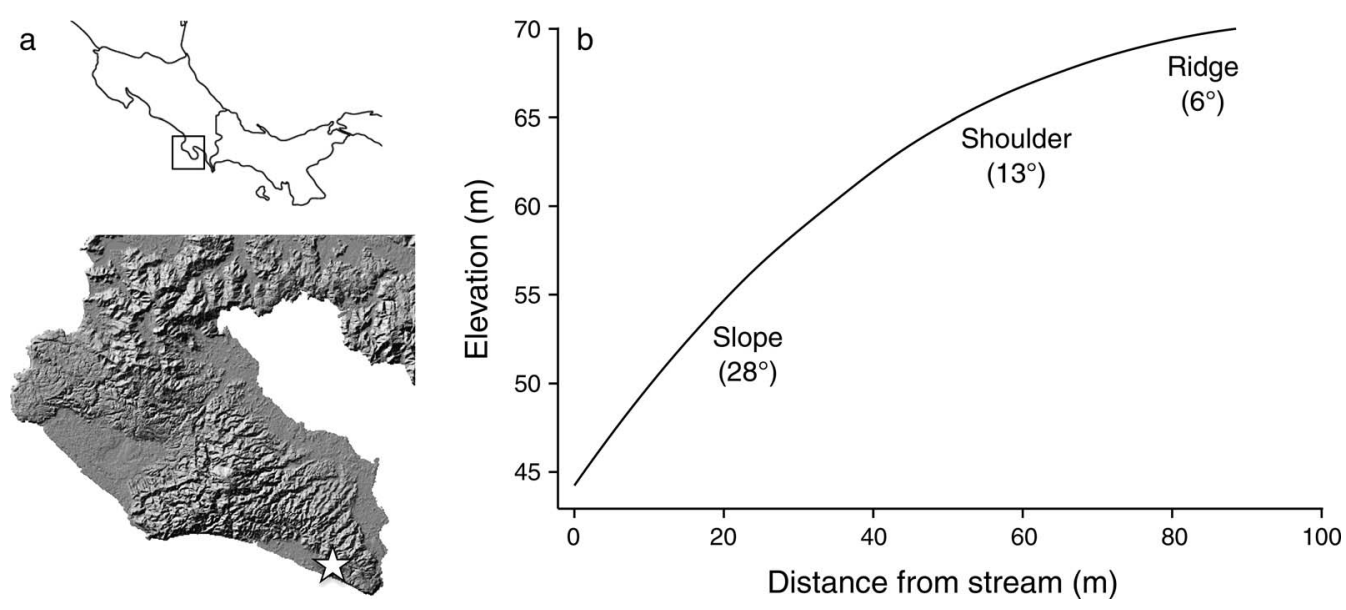

FIG. 1. (a) Map of Costa Rica and neighboring countries, with the Osa Peninsula highlighted, as well as a hillshade map of the Osa Peninsula with the study region indicated by a white star. (b) Smoothed elevational (meters above sea level) transect of the study toposequence, extracted from a $1.12 \times 1.12 \mathrm{~m}$ digital elevation model.

southern Osa Peninsula, southwest Costa Rica $\left(8^{\circ} 24^{\prime} 42^{\prime \prime}\right.$ $\left.\mathrm{N}, 83^{\circ} 20^{\prime} 00^{\prime \prime} \mathrm{W}\right)$. The study forest is carbon-dense with large-statured trees (mean canopy height of $45 \mathrm{~m} ; \mathrm{P}$. G. Taylor et al., unpublished data), contains a diverse assemblage of canopy and understory plants (Weber et al. 2001), and has no known history of deforestation or land-use change. The area receives $\sim 3400 \mathrm{~mm}$ of rain per year and has a mean annual temperature of $26^{\circ} \mathrm{C}$. Rainfall is distinctly seasonal; from January to March (the dry season), rainfall averages less than $100 \mathrm{~mm}$ per month; thereafter, heavy rains are common, with peak rains from September to November.

Soils of the Osa Peninsula are predominantly Ultisols, with areas of Inceptisols in steep regions and Entisols in alluvial zones (Berrange and Thorpe 1988). In the environs of the Rio Piro Research Station, soils are derived from Pliocene graywacke-type marine and continental conglomerates, sandstones, and siltstones, with sediments deposited in a turbid marine environment (Buchs et al. 2009, Gardner et al. 2013). These sedimentary formations, which may contain $\mathrm{N}$, unconformably overlay the basement rocks of the Osa Mélange (Cabo Matapalo Unit), which consist of a matrix of Eocene-Miocene limestones and basalts (Buchs et al. 2009, Gardner et al. 2013).

The peninsula is undergoing uplift at a long-term average rate between 1.7 and $8.5 \mathrm{~mm} / \mathrm{yr}$, due to the northeast-directed subduction of the aseismic Cocos Ridge beneath the Caribbean plate to its west (Gardner et al. 1992, 2013). This fast rate of uplift, combined with high rainfall, has created a highly dissected, geomorphologically dynamic landscape (Fig. 1a; Bern et al. 2007). Denudation rates have not been previously quantified for the region, but we estimated landscape lowering using the minimum eroded volume approach (Giaconia et al. 2012, Cooley 2013) and a highresolution digital elevation model (DEM) of our study site. Eroded volumes of three small, forested catchments
(10-15 ha) within the Piro Research Station were calculated from a $1.12 \times 1.12 \mathrm{~m}$ DEM, generated from airborne light detection and ranging (LiDAR) data by the Carnegie Airborne Observatory (Asner et al. 2012). Assuming local uplift rates of 2.2-2.5 mm/yr (Gardner et al. 2013), we calculated lowering rates of $\sim 0.1 \pm 0.02$ $\mathrm{mm} / \mathrm{yr}$. If local rock bulk density is $\sim 2.65 \mathrm{~g} / \mathrm{cm}^{3}$, this would equate to $\sim 2100 \pm 500 \mathrm{~kg} \cdot \mathrm{ha}^{-1} \cdot \mathrm{yr}^{-1}$ of material eroded from the catchments. Using a watershed monitoring approach, Taylor et al. (in press) recently measured catchment-scale fine suspended sediment exports of $1510 \mathrm{~kg} \cdot \mathrm{ha}^{-1} \cdot \mathrm{yr}^{-1}$ from a forest on the northwestern Osa Peninsula, with $14.5 \mathrm{~kg} \cdot \mathrm{ha}^{-1} \cdot \mathrm{yr}^{-1}$ of particulate organic $\mathrm{N}$ exported with this sediment (Taylor et al., in press). Though these two erosion estimates were generated using very different techniques, their similarity is notable and helps put quantitative constraints on regional erosion fluxes.

\section{Field and laboratory methods}

To investigate links between topography and $\mathrm{N}$ cycling in this landscape, we established a topographic sequence within a 12-ha headwater catchment of the Piro River. We focused on sampling the three dominant geomorphic landscape units found in our study region: (1) broad ridge crests, (2) gentle shoulder slopes, and (3) steep hillslopes bounded by streams. We established three $30 \mathrm{~m}$ long transects along the contours of a single ridge $\left(6^{\circ}\right)$ to shoulder $\left(13^{\circ}\right)$ to steep slope $\left(28^{\circ}\right)$ convex toposequence (Fig. 1b). Low-angle toe-slopes and concave floodplains are virtually absent in the study region (Bern et al. 2007), and thus were intentionally excluded from the study design. The distance between the upper- and lowermost transects was $90 \mathrm{~m}$ and the change in relative elevation was $25 \mathrm{~m}$.

In order to characterize broad trends in $\mathrm{N}$ cycling and availability at these three landscape positions, we measured a suite of soil $\mathrm{N}$ pools and process rates. 
While some of the variables measured integrate longterm processes and should thus be relatively time invariant, others were more likely to show temporal trends. For variables in the latter category, we measured pools and fluxes multiple times where possible in order to ensure patterns with topography were consistent over time. If only one measurement of a process was made, it was targeted to the period of peak biological activity at our site. (i.e., the mid-wet season). We collected 10 soil samples per position $(\sim 100 \mathrm{~g}$ each) from a $0-20 \mathrm{~cm}$ depth for analysis of $\delta^{15} \mathrm{~N}$ values in July 2010. Values of $\delta^{15} \mathrm{~N}$ are widely considered to be an integrated metric of ecosystem $\mathrm{N}$ status, as they are sensitive to rates and isotopic signatures of $\mathrm{N}$ inputs and losses (Handley et al. 1999, Martinelli et al. 1999, Brenner et al. 2001, Amundson et al. 2003). Soil samples were effectively free of coarse fragments; they were homogenized and roots were removed by hand, then they were transported to the University of Colorado (Boulder, Colorado, USA), where they were dried, ground to $20 \mu \mathrm{m}$, and sent to the Center for Stable Isotope Biogeochemistry at the University of California (Berkeley, California, USA) for isotopic analysis of bulk soil $\mathrm{N}$. The natural abundance of bulk soil ${ }^{15} \mathrm{~N}$ was calculated as: $\delta^{15} \mathrm{~N}(\%)=\left[\left(R_{\text {sample }} /\right.\right.$ $\left.\left.R_{\text {standard }}\right)-1\right] \times 1000$, where $R$ is the ratio of ${ }^{15} \mathrm{~N} /{ }^{14} \mathrm{~N}$ of the sample or standard (atmospheric $\mathrm{N}_{2}$ ). The standard deviation of the isotope measurements, determined using internal laboratory standards, was $0.1 \%$ (S. Mambelli, personal communication).

Four times over the course of the 2010 wet season (April, July, August, and October), soils were sampled for inorganic $\mathrm{N}$ by extracting $100-20 \mathrm{~cm}$ soil cores (separated by 3-4 $\mathrm{m}$ ) from along each transect. Within one day of soil collection for extractable $\mathrm{N}$, in situ soil nitrous oxide $\left(\mathrm{N}_{2} \mathrm{O}\right)$ emissions were also measured using pre-installed sampling collars $(n=10$ per transect) and following the field and laboratory methods described in detail in Wieder et al. (2011). For extractable N, $\sim 8 \mathrm{~g}$ fresh soil was added to $30 \mathrm{~mL}$ of $2 \mathrm{~mol} / \mathrm{L}$ potassium chloride $(\mathrm{KCl})$, then after $3 \mathrm{~h}$ of repeated shaking and 1 $\mathrm{h}$ of settling, solutions were filtered through $0.7-\mu \mathrm{m}$ Whatman glass fiber filters (GE Healthcare Bio-Sciences, Pittsburgh, Pennsylvania, USA) and frozen. Solutions were analyzed colorimetrically for ammonium $\left(\mathrm{NH}_{4}{ }^{+}\right.$) using a Synergy HT microplate reader (Biotek, Highland Park, Vermont, USA) and nitrate $\left(\mathrm{NO}_{3}^{-}\right)$ using an Alpkem autoanalyzer (OI Analytical, College Station, Texas, USA) at the University of Colorado. Soil subsamples were dried at $105^{\circ} \mathrm{C}$ for $48 \mathrm{~h}$ and all measurements are reported on a dry-mass basis.

Rates of net $\mathrm{N}$ mineralization, net nitrification, and nitrification potential were determined for each landscape position in July 2011. Ten $0-20 \mathrm{~cm}$ soil samples were collected from each transect and split in two. One set of samples were used for immediate $\mathrm{KCl}$ extraction; the others were buried in a bag beneath the leaf litter for $5 \mathrm{~d}$, then extracted, filtered, and analyzed. Net rates were calculated as the difference between initial and day-5 total inorganic $\mathrm{N}$ for $\mathrm{N}$ mineralization and $\mathrm{NO}_{3}{ }^{-}$for net nitrification (Hart et al. 1994). Fresh subsamples from this collection were transported to the University of Colorado for analysis of nitrification potential. In the laboratory, $10 \mathrm{~g}$ of soil was added to $100 \mathrm{~mL}$ of a 0.5 $\mathrm{mmol} / \mathrm{L} \mathrm{NH}_{4}{ }^{+}-\mathrm{N}$ buffer solution (Stark and Firestone 1996). A $10-\mathrm{mL}$ subsample of this slurry was immediately removed, filtered, and analyzed colorimetrically for $\mathrm{NO}_{3}^{-}$. The remaining slurry was incubated aerobically in the dark on an orbital shaker for $24 \mathrm{~h}$, followed by filtration and colorimetric analysis. The nitrification potential was calculated as the difference in initial and final $\mathrm{NO}_{3}{ }^{-}$concentrations.

To place measurements of $\mathrm{N}$ pools and fluxes in the context of longer-term soil development trends, a host of soil chemical, physical, and mineralogical properties was measured along the toposequence. We sampled 10 soil profiles per transect to a depth of $1 \mathrm{~m}$ in $20 \mathrm{~cm}$ depth increments using a $3 \mathrm{~cm}$ diameter soil sampling tube. Samples, effectively free of coarse fragments, were homogenized and roots were removed by hand. At the University of Colorado, soils were dried, ground to 20 $\mu \mathrm{m}$, weighed into tin capsules, and analyzed for bulk C and N (\%) using a Carlo Erba EA 1110 elemental analyzer (CE Elantech, Lakewood, New Jersey, USA). $\mathrm{C}$ and $\mathrm{N}$ inventories for each soil depth were calculated by multiplying soil bulk density $\left(\mathrm{g} / \mathrm{cm}^{3}\right)$ by $\mathrm{C}$ or $\mathrm{N}$ concentration (\%) by the depth interval $(\mathrm{cm})$, with no correction for coarse fragments, as they are effectively absent from these highly weathered tropical soils. Bulk density was estimated by digging pits down to $1 \mathrm{~m}$ near each transect $(n=2)$ and using a $6 \mathrm{~cm}$ diameter bulk density corer ( $154 \mathrm{~cm}^{3}$ volume) to remove soil from the center of each depth interval. This soil was subsequently dried at $105^{\circ} \mathrm{C}$ for $48 \mathrm{~h}$.

Soil particle size distributions were measured on a subset of soils from upper and lower horizons $(n=3$ per transect per depth interval) at the University of Montana (Missoula, Montana, USA) using laser diffraction and a Malvern Mastersizer 2000e (Malvern Instruments, Worcestershire, UK), following the methods recommended by Sperazza et al. (2004). A sodium hexametaphosphate solution $(5.5 \mathrm{~g} / \mathrm{L})$ was used as a dispersant, the pump speed was set to $2000 \mathrm{rpm}$, obscuration was mostly between $10 \%$ and $20 \%$, and the particle refractive index was set to 1.57 while absorption was set to 1 . The quantitative mineralogic composition was determined for a subset of $0-20 \mathrm{~cm}$ depth surface soils $(n=4$ composite samples per transect) using X-ray diffraction (XRD) with a D5000 $\mathrm{x}$-ray diffractometer (Siemens, Munich, Germany) in the University of Colorado Sediment Analysis Laboratory, following the protocol outlined in Dühnforth et al. (2012). XRD samples were treated with hydrogen peroxide to remove organics, dried, and ground to 20 $\mu \mathrm{m}$ in a McCrone mill with a zinc oxide internal standard. We prepared random mounts, and XRD patterns were collected for $5-65^{\circ} 2 \theta$ with a $0.02^{\circ}$ step 
size. The RockJock software (Erbel 2003) was used to assign mineral identity and mass percentages. The $\mathrm{pH}$ of surface soils was measured using an Accumet AB15 pH meter (Fisher Scientific, Pittsburgh, Pennsylvania, USA) with a 1:1 soil to deionized water ratio and a half-hour equilibration period.

Finally, in order to expand our exploration of links between topography and $\mathrm{N}$ cycling to the larger study landscape, we measured soil $\delta^{15} \mathrm{~N}$ values at 26 distinct locations spanning the range of slope angle variability found in the local forests $\left(\geq 5^{\circ}\right.$ to $\left.\sim 45^{\circ}\right)$. This sampling was conducted within a 50 -ha area and a 100 -m range in elevation, such that climate and forest type of the sampled locations did not vary. The lowest slope angles corresponded to convex ridge top and shoulder slope positions; low-angle toe-slopes and concave floodplains (virtually absent in this region) were not part of the sampling. At each location, surface litter was removed and a shallow mineral soil sample $(0-10 \mathrm{~cm}$ depth, $\sim 100$ g) was collected. Soils were effectively free of coarse fragments; they were homogenized and roots were removed by hand. Global positioning system (GPS) coordinates were recorded so that surface slope angles of the sampling locations could be calculated using the LiDAR DEM of the study site. Samples were analyzed for bulk soil $\delta^{15} \mathrm{~N}$ values by the Center for Stable Isotope Biogeochemistry at the University of California.

\section{Statistical analyses}

We employed a multivariate approach to examine whether $\mathrm{N}$-cycle profiles differed significantly $(\alpha=0.05)$ along the toposequence. Eight measurements of soil $\mathrm{N}$ pools and fluxes at the three landscape positions were used for this multivariate analysis: soil $\delta^{15} \mathrm{~N}$ values; mean extractable $\mathrm{NH}_{4}{ }^{+}$and $\mathrm{NO}_{3}{ }^{-}$and mean $\mathrm{N}_{2} \mathrm{O}$ fluxes from the 2010 wet season; net nitrification and net mineralization rates; the ratio of net nitrification to net $\mathrm{N}$ mineralization; and nitrification potentials. These metrics were used to create a distance matrix and conduct a principal components analysis (PCA) and PERMANOVA test to examine differences in integrated $\mathrm{N}$-cycle characteristics with landscape position.

The eight $\mathrm{N}$-cycle metrics were also analyzed individually to examine which ones differed by landscape position. Mixed-effects models were employed, with geomorphic position as a fixed effect and sampling location along each transect as a random effect, in order to account for nonindependence of samples collected along the transects (Zuur et al. 2010). Date was also initially included as a fixed effect in linear models for $\left[\mathrm{NH}_{4}{ }^{+}\right],\left[\mathrm{NO}_{3}{ }^{-}\right]$, and $\mathrm{N}_{2} \mathrm{O}$ flux, as these metrics were measured multiple times over the 2010 wet season. However, since there were no significant interactions between date and geomorphic position, and seasonal variation in these variables was not the main focus of the study, we used plot means for the final analyses in order to exclude the date variable and focus on the effects of landscape position.
Response variables were either natural-log- or squareroot-transformed if residuals were heteroscedastic. Although autocorrelation between measured variables was generally low (only three of 28 Spearman rank correlation tests returned $\rho$ values $>0.7$ ), both unadjusted and Bonferroni-adjusted $P$ values were calculated in order to account for multiple comparisons. The latter were derived by multiplying the former by eight, i.e., the number of comparisons made.

A similar mixed-model approach was used to test for differences in surface soil $(0-20 \mathrm{~cm}) \mathrm{C}$ and $\mathrm{N}$ concentrations, $\mathrm{C}: \mathrm{N}$ ratios, and $\mathrm{pH}$, as well as total $\mathrm{C}$ and $\mathrm{N}$ stocks in the top 20,40 , and $100 \mathrm{~cm}$ of soils across the toposequence. A regression coefficient for the log of $\mathrm{C}$ or $\mathrm{N}$ pool vs. the log of depth below the surface was calculated for each of the 10 profiles per transect. Differences in these regression slopes by landscape position were then tested using mixed models. Again, we report both unadjusted and Bonferroni-adjusted $P$ values from these statistical tests in order to account for multiple comparisons. In this case, unadjusted $P$ values were multiplied by 12 . Means and standard deviations for soil particle size and mineralogy data were calculated, but statistical tests were not conducted due to small sample sizes.

Finally, linear regression was used to examine the relationship between soil $\delta^{15} \mathrm{~N}$ and the sin of surface slope angle $(\theta)$ in the larger landscape sampling. DEMbased slope angles at a $10 \mathrm{~m}$ length scale were used for this analysis, and a Moran's I test was conducted to assess whether the residuals of this model were spatially autocorrelated. Pearson correlation was also used to examine the relationship between surface soil $\mathrm{C}: \mathrm{N}$ and $\delta^{15} \mathrm{~N}$, including data from the toposequence as well as the wider landscape sampling. Statistical analyses were conducted using R (R Development Core Team 2011).

\section{RESULTS}

The PCA and PERMANOVA test revealed significant (all $\alpha=0.05$ ) differences in $\mathrm{N}$-cycle profiles with landscape position $\left(F_{2,25}=10.47, P=0.001, R^{2}=0.46\right.$; Fig. 2). Ridge and steep slope positions had the most dissimilar N-cycle profiles, while the shoulder slope was intermediate. Axis 1 of the N-metrics PCA, which explained $49.4 \%$ of the variance in $\mathrm{N}$ cycling profiles (Fig. 2), was driven by metrics associated with production or accumulation of soil nitrate, including mean extractable $\mathrm{NO}_{3}{ }^{-}$concentrations, net nitrification rate, and nitrification potential rate.

When examined individually, six of the eight $\mathrm{N}$ metrics differed substantially among landscape positions (Fig. 3; Appendix: Table A1). Ridge soil $\mathrm{NO}_{3}{ }^{-}$concentrations $(1.78 \pm 0.25 \mu \mathrm{g} \mathrm{N} / \mathrm{g})$, net nitrification rates $(0.33 \pm 0.09$ $\left.\mu \mathrm{g} \mathrm{N} \cdot \mathrm{g}^{-1} \cdot \mathrm{d}^{-1}\right)$, and nitrification potentials $(10.12 \pm 2.1 \mu \mathrm{g}$ $\left.\mathrm{N} \cdot \mathrm{g}^{-1} \cdot \mathrm{d}^{-1}\right)$ were all at least an order of magnitude higher $\left(P<0.001\right.$ and $P_{\text {Bon }}<0.005$ for pairwise comparisons $)$ than respective pools and fluxes on the slope. Net $\mathrm{N}$ mineralization rates did not vary with landscape position, 


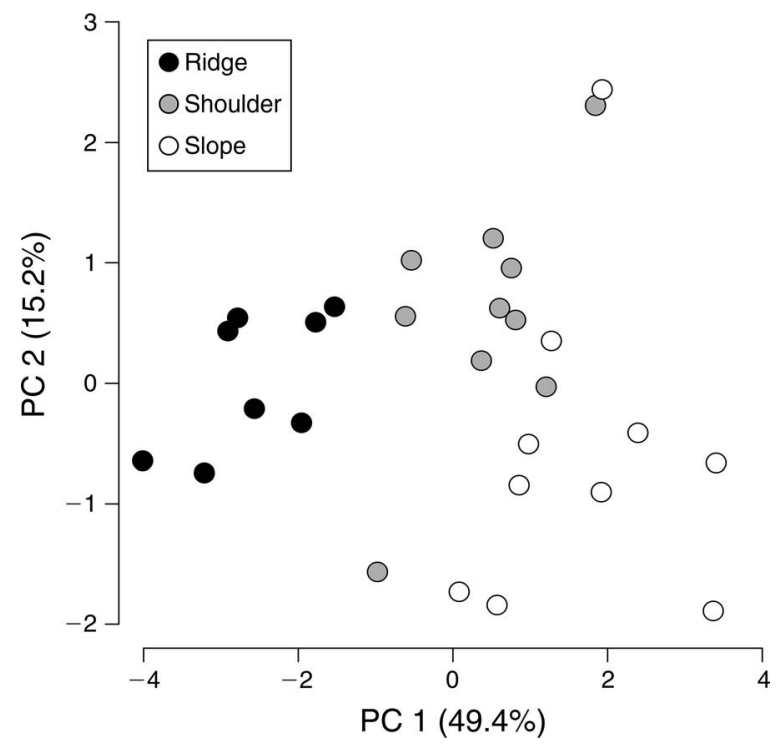

FIG. 2. Principal components (PC) analysis of soil N cycling at the three landscape positions, using eight $\mathrm{N}$-cycle metrics including soil $\delta^{15} \mathrm{~N}$ values, mean extractable $\mathrm{NH}_{4}{ }^{+}$and $\mathrm{NO}_{3}{ }^{-}$, mean $\mathrm{N}_{2} \mathrm{O}$ fluxes, net nitrification (nit) and mineralization (min) rates, ratios of net nitrification to mineralization (nit: $\min$ ), and nitrification potentials. Percentage of variance explained by each PC is shown in parentheses.

but the ratio of net nitrification to net mineralization tended to vary $\left(F_{2,16}=4.56, P=0.027\right.$ and $\left.P_{\text {Bon }}=0.137\right)$ and exceeded 1 only on the ridge (Appendix: Table A1). For five of the six metrics that displayed notable variation with topographic position, shoulder and steep slope soils were similar to each other but significantly different from the ridge. The exception to this was $\delta^{15} \mathrm{~N}$ values, which were similar on the ridge and shoulder $(\sim 6.3 \%$ o $\pm 0.1 \%$ o $)$ but different on the slope $\left(5.1 \% \pm \pm 0.2 \%\right.$ ). Soil $\mathrm{N}_{2} \mathrm{O}$ fluxes (grand mean $\sim 0.5 \pm 0.1 \mathrm{ng} \mathrm{N} \cdot \mathrm{cm}^{-2} \cdot \mathrm{h}^{-1}$ ) did not vary significantly by landscape position (Fig. 3; Appendix: Table A1).

Both concentrations and total stocks of soil $\mathrm{C}$ and $\mathrm{N}$ varied significantly with landscape position (Table 1). Ridge soils had higher surface C concentrations (4.0\%) compared to lower soil $\mathrm{C}$ in shoulder and slope soils $(\sim 2.9 \%)$. Surface soil N concentrations were highest on the ridge $(0.4 \%)$, intermediate on the shoulder $(0.3 \%)$, and lowest on the slope $(0.25 \%)$. Surface soil C:N ratios (mass basis) were significantly higher on the steep slope (11.8) compared to other landscape positions $(\sim 10)$. Integrated to $1 \mathrm{~m}$ depth, ridge soils contained the most $\mathrm{C}$ and $\mathrm{N}$, followed by the shoulder, with steep slopes containing roughly half of the $\mathrm{C}$ and $\mathrm{N}$ found in ridge tops (Table 1; Appendix: Tables A2 and A3). Stocks declined with depth below the surface most strongly in the steep part of the landscape, displaying a more modest decline with depth on the ridge and shoulder slope (Fig. 4). The regression coefficients of these relationships differed for $\mathrm{C}\left(F_{2,27}=7.0, P=0.006, P_{\text {Bon }}\right.$ $=0.068)$ and $\mathrm{N}\left(F_{2,26}=8.9, P=0.002, P_{\text {Bon }}=0.027\right)$.

Soils displayed distinct physical and mineralogical characteristics along the toposequence. Fine silt particles $(2-30 \mu \mathrm{m})$ dominated soil profiles across the study site $(55-70 \%$ by mass $)$, while clays $(<2 \mu \mathrm{m})$ only accounted for $10-15 \%$ of soil particles at the surface. However, ridge profiles contained a zone of clay accumulation at $1 \mathrm{~m}$ depth, where clay enrichment compared to the surface was $127 \%$ (Table 2). By contrast, we observed no change in the mass percentage of clay at depth on the slope $(0 \%)$ and only moderate clay accumulation at depth on the shoulder (48\%). Surface soils on the ridge contained $\sim 13 \%$ gibbsite (a completely desilicated aluminum hydroxide mineral), whereas slope soils contained only $\sim 0.05 \%$ gibbsite, and were more abundant in siliceous aluminum-bearing

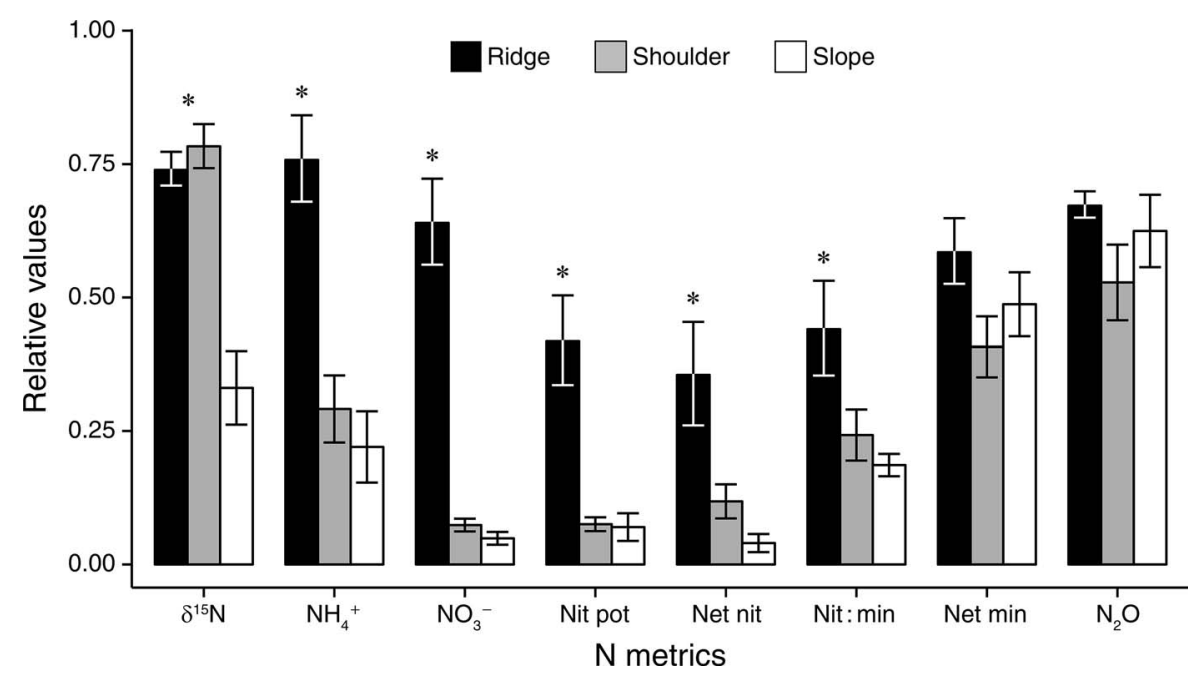

FIG. 3. Relative values of eight soil $\mathrm{N}$ metrics (mean \pm SE; see Fig. 2 caption for metric descriptions), centered by the minimum and scaled by the range for each assay $(x=x-\min (x) / \max (x)-\min (x))$, with significant effects of landscape position based on ANOVA of mixed-effects models shown. ${ }^{*} P<0.05$. 
TABle 1. Soil $\mathrm{C}$ and $\mathrm{N}$ and $\delta^{15} \mathrm{~N}$ values at the three landscape positions.

\begin{tabular}{|c|c|c|c|c|c|c|}
\hline Properties & Ridge & Shoulder & Slope & $F_{2,18}$ & $P$ & $P_{\text {Bon }}$ \\
\hline Soil C (\%) & $4.00^{\mathrm{a}}(0.17)$ & $2.87^{\mathrm{b}}(0.12)$ & $2.86^{\mathrm{b}}(0.23)$ & 14.46 & $<0.001$ & 0.002 \\
\hline Soil N (\%) & $0.39^{\mathrm{a}}(0.01)$ & $0.29^{\mathrm{a}, \mathrm{b}}(0.01)$ & $0.24^{\mathrm{b}}(0.01)$ & 39.75 & $<0.001$ & $<0.001$ \\
\hline Soil C:N & $10.3^{\mathrm{a}}(0.17)$ & $10.0^{\mathrm{a}}(0.16)$ & $11.8^{\mathrm{b}}(0.32)$ & 17.33 & $<0.001$ & $<0.001$ \\
\hline$\delta^{15} \mathrm{~N}(\%)$ & $6.22^{\mathrm{a}}(0.12)$ & $6.43^{\mathrm{a}}(0.13)$ & $5.07^{\mathrm{b}}(0.23)$ & 19.69 & $<0.001$ & $<0.001$ \\
\hline \multicolumn{7}{|c|}{ C stocks $\left(\mathrm{kg} / \mathrm{m}^{2}\right)$} \\
\hline $20 \mathrm{~cm}$ & $5.33(0.22)$ & $4.28(0.18)$ & $4.30(0.35)$ & 5.77 & 0.011 & 0.116 \\
\hline $40 \mathrm{~cm}$ & $8.67^{\mathrm{a}}(0.28)$ & $6.70^{\mathrm{b}}(0.21)$ & $6.33^{\mathrm{b}}(0.49)$ & 13.25 & $<0.001$ & 0.002 \\
\hline $100 \mathrm{~cm}$ & $14.47^{\mathrm{a}}(0.33)$ & $11.56^{\mathrm{b}}(0.42)$ & $8.85^{\mathrm{c}}(0.47)$ & 46.97 & $<0.001$ & $<0.001$ \\
\hline \multicolumn{7}{|c|}{$\mathrm{N}$ stocks $\left(\mathrm{kg} / \mathrm{m}^{2}\right)$} \\
\hline $20 \mathrm{~cm}$ & $0.51^{\mathrm{a}}(0.02)$ & $0.43^{\mathrm{b}}(0.01)$ & $0.36^{\mathrm{c}}(0.02)$ & 20.45 & $<0.001$ & $<0.001$ \\
\hline $40 \mathrm{~cm}$ & $0.84^{\mathrm{a}}(0.03)$ & $0.67^{\mathrm{b}}(0.02)$ & $0.55^{\mathrm{c}}(0.04)$ & 24.82 & $<0.001$ & $<0.001$ \\
\hline $100 \mathrm{~cm}$ & $1.42^{\mathrm{a}}(0.03)$ & $1.16^{\mathrm{b}}(0.04)$ & $0.76^{\mathrm{c}}(0.06)$ & 41.23 & $<0.001$ & $<0.001$ \\
\hline
\end{tabular}

Notes: Values are means, with SE in parentheses, and different superscripted letters indicate significant $(\alpha=0.05)$ differences between positions according to Bonferroni-adjusted $P$ values. Concentrations and $\delta^{15} \mathrm{~N}$ values are for surface soils, $0-20 \mathrm{~cm}$ depth, stocks are taken at three soil depths.

secondary minerals such as halloysite and kaolinite (Table 2). Thus, the ratio of gibbsite/(gibbsite + halloysite + kaolinite), which is often an indicator of the degree of chemical weathering in tropical soils (Johnsson and Stallard 1989, Fisher and Ryan 2006, Kleber et al. 2007), was an order of magnitude larger on the ridge than it was on the slope. Ridge and shoulder slope soils were more enriched in quartz compared to the slope soils, while slopes had double the abundance of 2:1 clays (illite + smectite).

Finally, with a more widespread sampling of the study landscape, a significant negative linear relationship between surface slope angle and soil $\delta^{15} \mathrm{~N}$ values was observed $\left(F_{1,24}=32.6, P<0.001, R^{2}=0.58\right.$; Fig. 5 and Appendix: Table A4). The residuals of this model were not significantly spatially autocorrelated (Moran's $I=$ $-0.20, P=0.177)$. There was also a strong, negative linear association between soil $\mathrm{C}: \mathrm{N}$ ratios and $\delta^{15} \mathrm{~N}$ values $(P<0.001, R=-0.88$; Fig. 6)

\section{DisCUSSION}

Variation in soil residence time and weathering status has been invoked to explain changes in relative nutrient content and constraints over large spatial gradients (i.e., high vs. low latitudes) and through time (i.e., chronosequences; Walker and Syers 1976, Vitousek and Farrington 1997, Hedin et al. 2003, Reich and Oleksyn 2004, Porder and Hilley 2011). The results presented here concur with other studies suggesting nutrient cycling dynamics and patterns of limitation may vary as much at local scales in dissected landscapes as they do across large spatial gradients and long time periods. This phenomenon and its drivers have been studied in the context of $\mathrm{P}$ availability (Scatena and Lugo 1995, Vitousek et al. 2003,
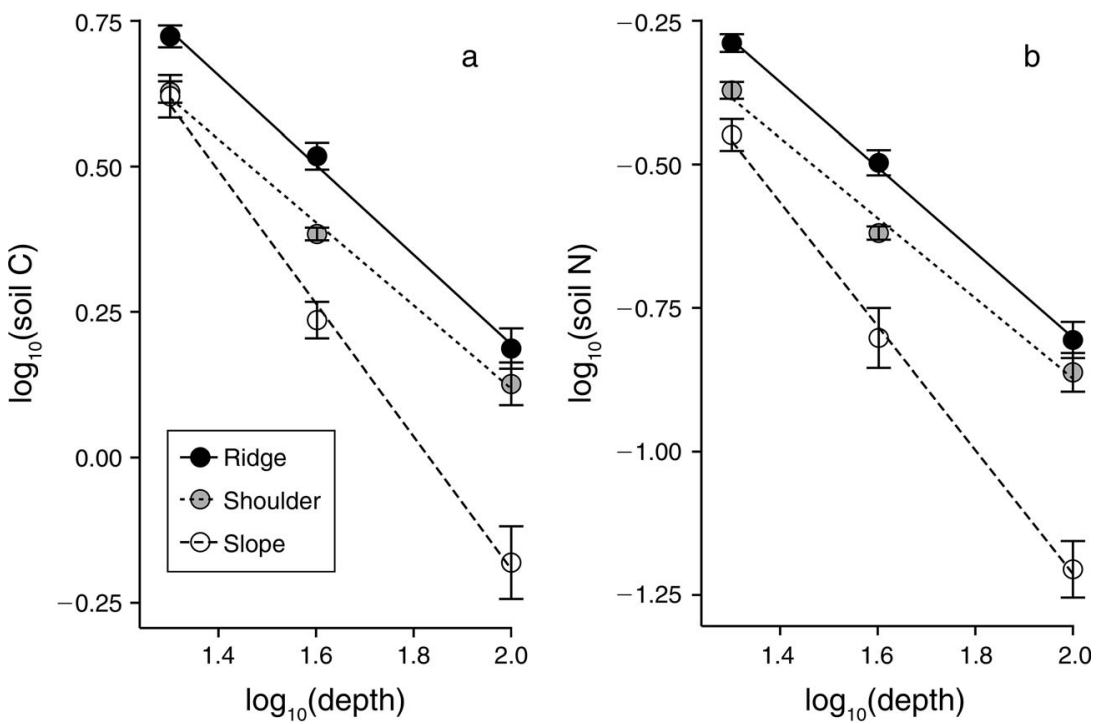

FIG. 4. Log-log relationships between (a) soil C and (b) soil $\mathrm{N}$ stocks (both shown with $\pm \mathrm{SE}$; both originally measured in $\mathrm{kg} /$ $\mathrm{m}^{2}$ ) and depth below the surface (originally measured in $\mathrm{cm}$ ). Regression coefficients for the slope were significantly different compared to ridge and shoulder for both $\mathrm{C}$ and $\mathrm{N}$. 
TABLE 2. Soil fine fraction physico-chemical and mineralogical properties at the three landscape positions.

\begin{tabular}{lccc}
\hline \hline \multicolumn{1}{c}{ Properties } & Ridge & Shoulder & Slope \\
\hline Particle size distribution (sand : silt : clay) & & & \\
$0-20 \mathrm{~cm}$ & $15: 74: 11$ & $14: 70: 16$ & $13: 74: 13$ \\
$\quad 80-100 \mathrm{~cm}$ & $13: 62: 25$ & $19: 58: 23$ & $16: 71: 13$ \\
Clay enrichment $(\%)$ & 127 & 44 & 0 \\
Bulk density $\left(\mathrm{g} / \mathrm{cm}^{3}\right)$ & 0.67 & 0.74 & 0.75 \\
$\mathrm{~Gb} /(\mathrm{Gb}+\mathrm{Hal}+\mathrm{Kao})$ & $0.31(0.04)$ & $0.21(0.04)$ & $0.02(0.02)$ \\
Smectite + illite (mass percentage) & $4.8(1.4)$ & $5.4(1.3)$ & $11.0(3.5)$ \\
Quartz (mass percentage) & $27.4(2.5)$ & $25.8(3.6)$ & $17.6(4.0)$ \\
Soil pH & $6.21^{\mathrm{a}}(0.06)$ & $5.72^{\mathrm{b}}(0.07)$ & $5.63^{\mathrm{b}}(0.06)$ \\
\hline
\end{tabular}

Notes: Values are means, with SE in parentheses, and different superscripted letters indicate significant $(\alpha=0.05)$ differences between positions. For particle size distribution, $n=3$ samples; bulk density, $n=2$; for mineralogy, $n=4$; for $\mathrm{pH}, n=10$. For mineralogy, relationship between gibbsite $(\mathrm{Gb})$, halloysite ( $\mathrm{Hal})$, and kaolinite (Kao) is shown. Particle size distribution is shown at two soil depths.

Porder et al. 2005), but our results suggest topographic effects on $\mathrm{N}$ may be equally important to consider.

Evidence that $\mathrm{N}$ dynamics vary substantially with topography in this dissected forest comes from detailed work along the topographic sequence as well as broader sampling of the landscape. Of eight $\mathrm{N}$-cycle metrics measured along the toposequence, six implied $\mathrm{N}$-poor conditions on the steep slope when compared with higher $\mathrm{N}$ availability and relatively $\mathrm{N}$-rich conditions on the flat ridge top (Fig. 3). Soil nitrate pools, net nitrate production rates, the ratio of net nitrate production to net $\mathrm{N}$ mineralization, and nitrification potential rates all approached detection limits on the steep slope but were substantially and significantly higher on the flat ridge.
The gently sloping zone (i.e., shoulder) exhibited N-cycle properties that were intermediate (Fig. 2), sharing some characteristics with both end-members. Not only were inorganic $\mathrm{N}$ pools and nitrate production rates low on the steep slope, but total soil $\mathrm{N}$ concentrations were also lower and $\mathrm{C}: \mathrm{N}$ ratios were higher compared to the ridge. Thus, while $\mathrm{N}$ limitation on the steep slope was not assessed directly, the picture of $\mathrm{N}$ availability painted by the multiple indicators measured did not suggest $\mathrm{N}$ cycling in excess of demand. Instead, the $\mathrm{N}$ cycle on steep slopes appeared more similar to young or recently disturbed tropical forests (e.g., Hall and Matson 2003, Davidson et al. 2007) which tend to experience $\mathrm{N}$ constraints to ecosystem processes (Davidson et al. 2004).
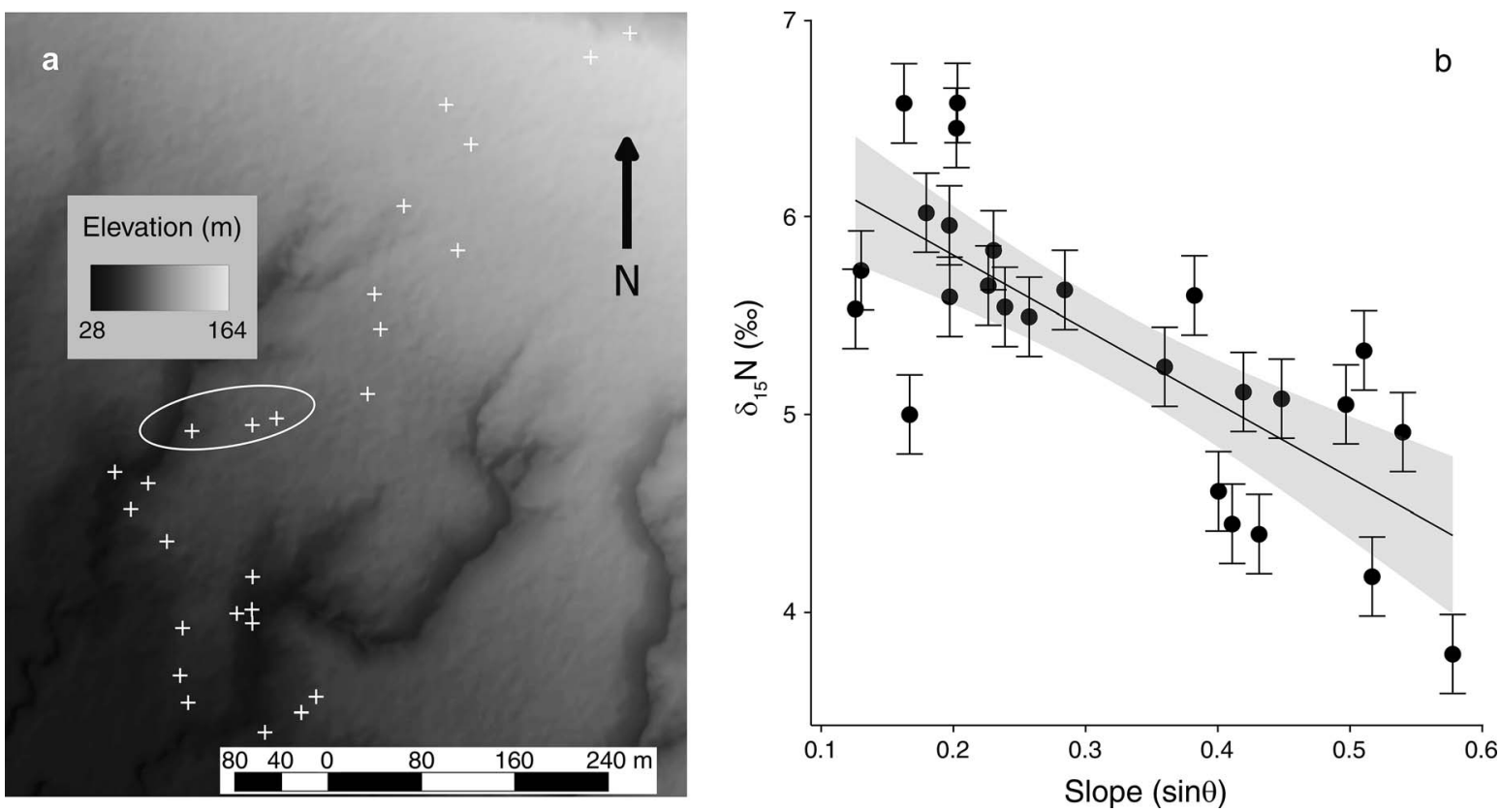

FIG. 5. (a) Digital elevation map of the study forest, with white crosses indicating sites of the larger landscape sampling and the white circle indicating location of the study toposequence. (b) Soil $\delta^{15} \mathrm{~N}$ values vs. slope angle from the larger landscape sampling, with error bars indicating two standard deviations of the isotope measurements. Gray shaded region is the $95 \%$ confidence interval for the linear regression: $\delta^{15} \mathrm{~N}=-3.745 \times$ slope $(\sin \theta)+6.553 ; R^{2}=0.576$. 
Patterns observed at the hillslope scale were in line with observations across the larger landscape, specifically the negative correlation between surface slope angle and soil $\delta^{15} \mathrm{~N}$ values (Fig. 5). High values of soil $\delta^{15} \mathrm{~N}$ are commonly attributed to large losses of $\mathrm{N}$ from biologically available pools (Austin and Vitousek 1998) and are thus interpreted as an indicator of N-rich conditions (Martinelli et al. 1999, McLauchlan et al. 2013). In the context of hillslopes, it has recently been argued that declining soil $\delta^{15} \mathrm{~N}$ values with increasing slope angles (similar to what we observed here) indicate a shift toward increased $\mathrm{N}$ loss from non-fractionating pathways, such as particulate $\mathrm{N}$ erosion and organic $\mathrm{N}$ leaching, relative to pathways that involve isotopic fractionation, such as nitrification-nitrate leaching or denitrification (Amundson et al. 2003, Hilton et al. 2013). This mechanism seems to fit with our empirical data from the toposequence, as we observed low nitrate abundance and production rates as well as lower surface soil $\mathrm{N}$ contents on high-angle sites. The negative relationship between slope angle and soil $\delta^{15} \mathrm{~N}$ values observed in this study is consistent with observations from montane tropical forests of Peru and Taiwan (Hilton et al. 2013), suggesting geomorphic controls on forms of $\mathrm{N}$ loss may be important across a wide range of incised tropical forests.

${ }^{15} \mathrm{~N}$ mass balance models can be used to quantitatively explore how variation in non-fractionating losses relates to $\mathrm{N}$ isotope patterns (Hilton et al. 2013). As soil and organic matter erosion increase relative to other (fractionating) N-loss pathways, the apparent fractionation factor of the ecosystem, a key parameter in steadystate ${ }^{15} \mathrm{~N}$ models, approaches 1 , or no fractionation during loss. This causes $\delta^{15} \mathrm{~N}$ values to approach those of inputs, which, if atmospheric, are near 0 . Following Hilton et al. (2013) and applying $\mathrm{N}$ isotope mass balance models parameterized for our site (Appendix: Table A5), the observed $\sim 3 \%$ o decline in $\delta^{15} \mathrm{~N}$ values from flat to steep regions can be explained by an increase in the contribution of non-fractionating losses (erosion and organic $\mathrm{N}$ leaching) from $0 \%$ to $45 \%$ of estimated annual $\mathrm{N}$ loss, translating to 0 to $4.5 \mathrm{~kg} \mathrm{~N} \cdot \mathrm{ha}^{-1} \cdot \mathrm{yr}^{-1}$ (Appendix: Fig. A1). While this non-fractionating steep slope $\mathrm{N}$-loss estimate is lower than the $14.9 \mathrm{~kg} \mathrm{~N} \cdot \mathrm{ha}^{-1} \cdot \mathrm{yr}^{-1}$ observed by Taylor et al. (in press), it is reasonable, given catchment-scale losses (as measured in that study) should include bank erosion and other near-channel sources of particulate $\mathrm{N}$.

Variation in particulate $\mathrm{N}$ erosion rates is thus a plausible explanation for the inverse relationships between $\mathrm{N}$ availability and $\delta^{15} \mathrm{~N}$ values with slope angle. However, other factors may influence $\mathrm{N}$ compound abundance and isotope ratios and merit consideration here. In steady-state ${ }^{15} \mathrm{~N}$ mass balance models, soil $\delta^{15} \mathrm{~N}$ values are a function of the ${ }^{15} \mathrm{~N} /{ }^{14} \mathrm{~N}$ ratios of inputs and the integrated, ecosystem-level fractionation factor of losses (Brenner et al. 2001, Amundson et al. 2003, Hilton et al. 2013). While ecosystem-level fractionation factors

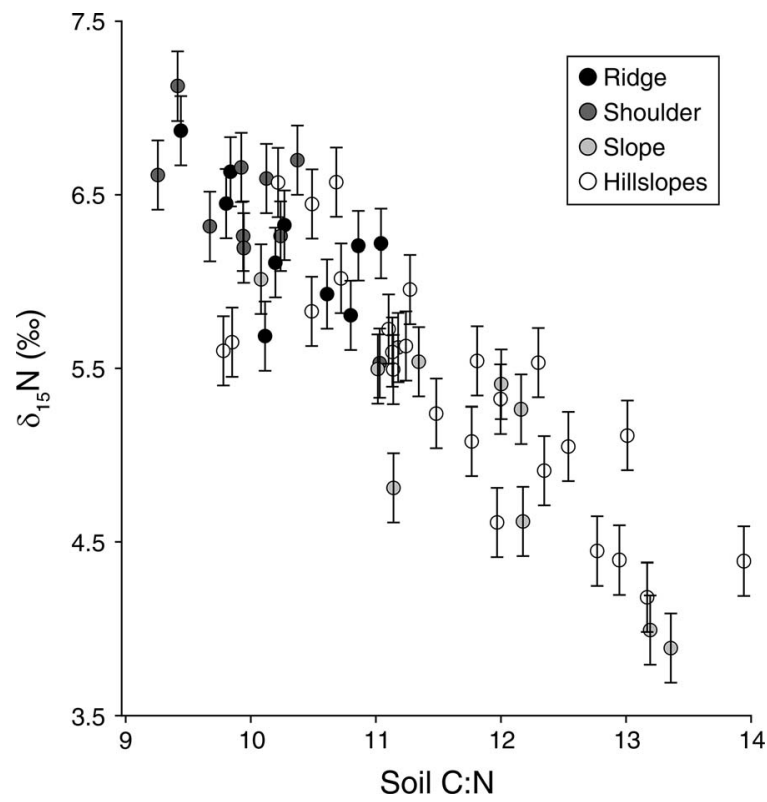

FIG. 6. Soil $\delta^{15} \mathrm{~N}$ values vs. soil C: $\mathrm{N}$ ratios across the study forest, including data from the toposequence as well as the wider landscape sampling. Error bars indicate two standard deviations of the isotope measurements.

varied in our models due to shifting contributions of fractionating and non-fractionating losses, the fractionation factor of fractionating losses $\left(\alpha_{\mathrm{f}}\right)$ was held constant. This was similar to previous work (Hilton et al. 2013), but was an important assumption because variation in this parameter can, in theory, explain changes in $\delta^{15} \mathrm{~N}$ without invoking non-fractionating losses. For instance, nitrate leaching has a smaller isotope effect (i.e., a fractionation factor closer to 1) compared to denitrification (Houlton and Bai 2009, Morford et al. 2011), so if leaching dominates relative to denitrification on steep slopes, this could account for the changes we observed in $\delta^{15} \mathrm{~N}$ values.

That said, our results suggest this scenario is unlikely. Soil $\mathrm{NO}_{3}^{-}$concentrations declined by an order of magnitude on the steep slope while $\mathrm{N}_{2} \mathrm{O}$ fluxes did not change. Knowledge of $\mathrm{N}_{2}$ fluxes and/or unsampled "hot moments" of denitrification could alter this interpretation, but our data imply that denitrification is in fact favored relative to leaching on slopes. This would decrease $\alpha_{\mathrm{f}}$ values and cause more slope soil $\mathrm{N}$ isotopic enrichment; the opposite of what we observed. Complete nitrate consumption and underexpression of the denitrifier isotope effect (Houlton et al. 2006) could reconcile observations of more relative gas loss and lower $\delta^{15} \mathrm{~N}$ enrichment on steep slopes, but such dynamics are not likely (though not impossible) on well-drained, high-gradient hillslopes. It is worth noting that $\mathrm{NO}_{3}^{-}$, dissolved organic $\mathrm{N}$, and $\mathrm{N}_{2} \mathrm{O}$ fluxes are dwarfed by particulate $\mathrm{N}$ loss rates at the watershed scale (Taylor et al., in press). Taken alongside our other edaphic data, a strong case emerges 
for linking erosive losses to isotopic and $\mathrm{N}$ availability trends across the landscape.

Variation in the size and form of $\mathrm{N}$ inputs may also contribute to the patterns we observed. For example, one could imagine shifts in biological $\mathrm{N}$ fixation rates across hillslopes in tropical forests, especially in response to changes in $\mathrm{P}$ fertility (Houlton et al. 2008). This additional nutrient-geomorphic coupling is an interesting (and untested) idea. However, at steady state, changes in $\mathrm{N}$ fixation rates would not affect soil $\delta^{15} \mathrm{~N}$ values without concurrent changes in some other $\mathrm{N}$ input process with unique $\delta^{15} \mathrm{~N}$ values. $\mathrm{N}$ inputs from the weathering of sedimentary rocks (Holloway and Dahlgren 2002, Morford et al. 2011) could be such a process.

The $\mathrm{N}$ content of southern Osa graywackes has not been measured, but it is possible that the sedimentary bedrock contains some $\mathrm{N}$. Based on denudation rate estimates (see Methods) and published values for global sedimentary rock $\mathrm{N}$ content $(200-800 \mathrm{ppm}$ on a mass basis; Goldblatt et al. 2009), rocks should not be the major $\mathrm{N}$ source in this forest. Even so, since bedrock $\mathrm{N}$ is likely to be isotopically heavy compared to the atmosphere, we explored how rock $\mathrm{N}$ inputs could affect isotope patterns using ${ }^{15} \mathrm{~N}$ mass balance models. We allowed the ${ }^{15} \mathrm{~N} /{ }^{14} \mathrm{~N}$ ratio of inputs to increase with slope angle, simulating changes in rock $\mathrm{N}$ inputs over a range of $\delta^{15} \mathrm{~N}$ values (1-6\%; Appendix: Fig. A2). Model results demonstrate that high rock $\mathrm{N}$ inputs on slopes require an even larger shift in the integrated ecosystem fractionation factor toward 1 to achieve observed $\mathrm{N}$ isotope patterns (Appendix: Fig. A2). We suggest this shift is most probably explained by an increase in erosive losses. Large inputs of bedrock $\mathrm{N}$ (especially if isotopically heavy) are difficult to reconcile with our suite of $\mathrm{N}$ cycle data, as nearly all soil $\mathrm{N}$ metrics indicate slopes, where weathering should be highest, are an Npoor (and ${ }^{15} \mathrm{~N}$-poor) part of the landscape. Though more information on the $\mathrm{N}$ content and isotopic composition of the bedrock would shed light on this issue, taken as a whole, our evidence suggests spatial variation in $\mathrm{N}$ inputs does not explain the patterns we observed, but rather that non-fractionating erosive $\mathrm{N}$ losses on steep slopes are the dominant driver.

The importance of nutrient losses from non-biologically available pools, commonly referred to as demandindependent losses, has been recognized for some time (Hedin et al. 1995, Perakis and Hedin 2002, Michaelides et al. 2012, Hilton et al. 2013). And yet, discussion of such losses to date has mostly concerned elements in dissolved phases. However, particulate nutrient losses associated with soil and organic matter can be of greater magnitude than dissolved losses in erosion-prone ecosystems (Shanley et al. 2011, Michaelides et al. 2012), including watersheds on the Osa Peninsula and beyond (Taylor et al., in press). Our data complement those of Taylor et al. (in press) by highlighting some of the upland biogeochemical and ecological consequences of elevated particulate $\mathrm{N}$ export from high-angle hillslopes; roughly $30 \%$ of the lowland forests in the immediate region of our study site (i.e., areas where surface slope angle $\geq 25^{\circ}$ ). These dynamics may be relevant to understanding the $\mathrm{N}$ cycle in diverse ecosystems possessing steep topography; erosive $\mathrm{N}$ fluxes and their impacts on spatial patterns of $\mathrm{N}$ availability thus deserve further investigation.

Distributions of soil organic matter and particle sizes support our hypothesis of linkages between the spatial pattern of erosion and soil $\mathrm{N}$ availability. On the ridge, larger soil $\mathrm{C}$ and $\mathrm{N}$ stocks, more organic matter at depth, and a zone of clay accumulation at $1 \mathrm{~m}$ (Table 1, Fig. 4) suggest soils are relatively stable and water translocates material vertically through soil profiles over time. On the slope, a sharp reduction in total soil $\mathrm{C}$ and $\mathrm{N}$ stocks, less organic matter at depth, and lack of deepsoil clay accumulation suggest that surface soil material is continuously removed. Taken together, these pedogenic traits point toward a mechanism for particulate $\mathrm{N}$ mobilization and transport on slopes. A combination of steep terrain and high-intensity storms, during which rainfall can exceed infiltration rates at depth in weathered tropical soils (Elsenbeer 2001, Lohse and Dietrich 2005, Murphy and Stallard 2012), may lead to overland flow and landslipping/sliding, moving nearsurface soil material downslope. Higher soil C:N ratios on the slope also point toward lower $\mathrm{N}$ availability there, and the negative correlation between soil C: $\mathrm{N}$ and $\delta^{15} \mathrm{~N}$ values (Fig. 6) further supports links between erosive, non-fractionating $\mathrm{N}$ losses and $\mathrm{N}$ availability.

Differences in soil mineralogy across the toposequence also correlate with $\mathrm{N}$ availability, suggesting a common geomorphic link. In flat tropical terrain where chemical erosion outpaces physical erosion, soils should be highly leached and posses stable mineral phases. On steeper slopes with higher physical erosion rates, incompletely weathered, unstable phases may persist (Stallard 1988, Thomas 1994). Findings from our study were consistent with this general pattern, as slopes harbored negligible amounts of gibbsite and contained a higher mass percentage of 2:1 clays, namely illite and smectite, compared to the ridge (Table 2). Slopes were also less enriched in quartz, a recalcitrant mineral that accumulates as soils develop (Birkeland 1999). In other tropical forests, similar variation in soil mineralogy has been attributed to differences in the duration of soil weathering (Johnsson and Stallard 1989, Fisher and Ryan 2006, Kleber et al. 2007); at our site, this would imply shorter soil residence times on $\mathrm{N}$ poor slopes compared to N-rich ridges. Soil hydrologic conditions (Kleber et al. 2007) and differential inheritance of minerals from bedrock are also known to influence soil mineralogy and may play a role here. However, intense chemical weathering during soil development in humid tropical environments tends to override initial mineral differences in bedrock, making physiography a defining characteristic for soil development trajectories (Johnsson and Stallard 1989, 
Thomas 1994). As such, duration of chemical weathering is a probable explanation for differences in soil mineralogical composition on steep vs. proximate flat terrain. That $\mathrm{N}$ availability (Vitousek 2004) and soil mineralogy both suggest variation in soil age or stability across the landscape is a notable finding.

While these results are compelling, the specific regional geomorphic and climatic settings are important to consider in exploring links between $\mathrm{N}$ availability and topography. Variation in surface slope angle may drive differences in erosive $\mathrm{N}$ losses, thereby creating heterogeneity in $\mathrm{N}$ constraints, across some dissected landscapes but not others. For instance, ridges and slopes did not exhibit differences in inorganic or total soil $\mathrm{N}$ concentrations along a toposequence in Manaus, Amazonia, Brazil (Luizao et al. 2004). This lack of difference in $\mathrm{N}$ availability may be a product of reduced erodability of hillslopes in that region compared to our site, resulting from differences in precipitation patterns (2200 vs. 3400 $\mathrm{mm}$ mean annual precipitation), steepness of slope angles (mean $6^{\circ}$ vs. $20^{\circ}$ ), and subsurface infiltration rates (Elsenbeer 2001). In general, tropical areas that posses high rainfall rates, steep terrain, and high rates of physical denudation have the greatest potential for erosion to mediate variation in nutrient cycling and availability with topography. This could include (but is not limited to): forested areas in Central America (Morell et al. 2012), Taiwan (Stolar et al. 2007), the Andean foothills (Dosseto et al. 2006), and Southeast Asia (Hovius et al. 1998). In low-gradient tropical regions where denudation rates are slower and dominated by chemical weathering (Stallard 1988), differences in nutrient availability along topographic sequences are more likely to be driven by transport and transformation of solutes (Lohse and Dietrich 2005, Chaves et al. 2009) or differences in soil type and redox status that affect soil nutrient retention capacity (Tiessen et al. 1994).

We do not assert that all ridges or hillcrests will be Nrich compared to hillslopes; instead, we suggest that spatial variation in soil erosion regimes (where present) may drive considerable heterogeneity in $\mathrm{N}$ cycling and availability, as has been shown for $\mathrm{P}$ and other rockderived nutrients. In lowland tropical forests, these dynamics could be added to the growing list of reasons why it is challenging to identify a single, specific limiting nutrient (Cleveland et al. 2011, Townsend at el. 2011). More broadly, elucidating links between $\mathrm{N}$ constraints and geomorphology will improve our fundamental understanding of $\mathrm{N}$ dynamics in complex terrain. In the context of environmental perturbations such as reactive $\mathrm{N}$ deposition and changes in climate, a better understanding of geomorphic controls on $\mathrm{N}$ availability and losses will help us predict biogeochemical responses in steepland ecosystems.

\section{ACKNOWLEDGMENTS}

We are grateful to Robert Stallard for his contribution to the ideas presented in the manuscript. Robert Anderson also provided insightful input, and feedback from Scott Morford and Robert Hilton substantially improved this work. Thanks are due to Osa Conservation for providing access to field sites, lodging, and research infrastructure. Walkom Cambronero Castro, Marvin Lopez Morales, Will Wieder, Rebecca Cole, and Adrienne Keller provided critical assistance with field and laboratory work. We thank Francisco Campos Rivera and the Organization for Tropical Studies (OTS) for assisting with research permits and providing logistical support in Costa Rica. Grants from the National Science Foundation (DEB-0515744 and DEB-0852916) provided support for this research.

\section{Literature Cited}

Ahnert, F. 1994. Equilibrium, scale and inheritance in geomorphology. Geomorphology 11:125-140.

Alvarez-Clare, S., M. C. Mack, and M. Brooks. 2013. A direct test of nitrogen and phosphorus limitation to net primary productivity in a lowland tropical wet forest. Ecology 94: $1540-1551$.

Amundson, R., A. T. Austin, E. A. G. Schuur, K. Yoo, V. Matzek, C. Kendall, A. Uebersax, D. Brenner, and W. T. Baisden. 2003. Global patterns of the isotopic composition of soil and plant nitrogen. Global Biogeochemical Cycles 17(1): 1031.

Amundson, R., and H. Jenny. 1997. On a state factor model of ecosystems. BioScience 47:536-543.

Asner, G. P., D. E. Knapp, J. Boardman, R. O. Green, T. Kennedy-Bowdoin, M. Eastwood, R. E. Martin, C. Anderson, and C. B. Field. 2012. Carnegie Airborne Observatory-2: increasing science data dimensionality via high-fidelity multisensor fusion. Remote Sensing of Environment 124:454-465.

Austin, A. T., and P. M. Vitousek. 1998. Nutrient dynamics on a precipitation gradient in Hawai'i. Oecologia 113:519-529.

Bern, C. R., S. Porder, and A. R. Townsend. 2007. Erosion and landscape development decouple strontium and sulfur in the transition to dominance by atmospheric inputs. Geoderma $142: 274-284$.

Berrange, J. P., and R. S. Thorpe. 1988. The geology, geochemistry and emplacement of the Cretaceous-Tertiary ophiolitic Nicoya Complex of the Osa Peninsula, southern Costa Rica. Tectonophysics 147:193-220.

Birkeland, P. W. 1999. Soils and geomorphology. Oxford University Press, New York, New York, USA.

Bonan, G. B. 2008. Forests and climate change: forcings, feedbacks, and the climate benefits of forests. Science 320: 1444-1449.

Brenner, D., R. Amundson, W. Baisden, C. Kendall, and J. Harden. 2001. Soil $\mathrm{N}$ and ${ }^{15} \mathrm{~N}$ variation with time in a California annual grassland ecosystem. Geochimica et Cosmochimica Acta 65:4171-4186.

Buchs, D. M., P. O. Baumgartner, C. Baumgartner-Mora, A. N. Bandini, S. J. Jackett, M. O. Diserens, and J. Stucki. 2009. Late Cretaceous to Miocene seamount accretion and mélange formation in the Osa and Burica Peninsulas (southern Costa Rica): episodic growth of a convergent margin. Geological Society, London, Special Publications 328:411-456.

Buss, H. L., R. Mathur, A. F. White, and S. L. Brantley. 2010. Phosphorus and iron cycling in deep saprolite, Luquillo Mountains, Puerto Rico. Chemical Geology 269:52-61.

Chapin, F. S., III, L. R. Walker, C. L. Fastie, and L. C. Sharman. 1994. Mechanisms of primary succession following deglaciation at Glacier Bay, Alaska. Ecological Monographs 64:149-175.

Chaves, J., C. Neill, S. Germer, S. Gouveia Neto, A. V. Krusche, A. Castellanos Bonilla, and H. Elsenbeer. 2009. Nitrogen transformations in flowpaths leading from soils to streams in Amazon forest and pasture. Ecosystems 12:961972. 
Clark, D. A. 2004. Tropical forests and global warming: slowing it down or speeding it up? Frontiers in Ecology and the Environment 2:73-80.

Cleveland, C. C., et al. 2011. Relationships among net primary productivity, nutrients and climate in tropical rain forest: a pan-tropical analysis. Ecology Letters 14:939-947.

Cooley, S. 2013. GIS 4 geomorphology. http:// gis4geomorphology.com

Crews, T. E., K. Kitayama, J. H. Fownes, R. H. Riley, D. A. Herbert, D. Mueller-Dombois, and P. M. Vitousek. 1995. Changes in soil phosphorus fractions and ecosystem dynamics across a long chronosequence in Hawaii. Ecology 76: $1407-1424$.

Cuevas, E., and E. Medina. 1986. Nutrient dynamics within Amazonian forest ecosystems. I. Nutrient flux in fine litter fall. Oecologia 68:466-472.

Davidson, E. A., et al. 2007. Recuperation of nitrogen cycling in Amazonian forests following agricultural abandonment. Nature 447:995-998.

Davidson, E. A., C. J. R. de Carvalho, I. C. G. Vieira, R. de O. Figueiredo, P. Moutinho, F. Y. Ishida, M. T. P. dos Santos, J. B. Guerrero, K. Kalif, and R. T. Sabá. 2004. Nitrogen and phosphorus limitation of biomass growth in a tropical secondary forest. Ecological Applications 14(Supplement): S150-S163.

Dosseto, A., B. Bourdon, J. Gaillardet, L. Maurice-Bourgoin, and C. J. Allegre. 2006. Weathering and transport of sediments in the Bolivian Andes: time constraints from uranium-series isotopes. Earth and Planetary Science Letters 248:759-771.

Dühnforth, M., R. S. Anderson, D. J. Ward, and A. Blum. 2012. Unsteady late Pleistocene incision of streams bounding the Colorado Front Range from measurements of meteoric and in situ ${ }^{10} \mathrm{Be}$. Journal of Geophysical Research 117: F01023.

Elsenbeer, H. 2001. Hydrologic flowpaths in tropical rainforest soilscapes: a review. Hydrological Processes 15:1751-1759.

Erbel, D. 2003. User's guide to Rockjock - a program for determining quantitative mineralogy from powder X-ray diffraction data. Open-file report 03-78. U.S. Geological Survey, Boulder, Colorado, USA.

Fisher, G. B., and P. C. Ryan. 2006. The smectite-to-disordered kaolinite transition in a tropical soil chronosequence, Pacific Coast, Costa Rica. Clays and Clay Minerals 54:571-586.

Gardner, T. W., D. M. Fisher, K. D. Morell, and M. L. Cupper. 2013. Upper-plate deformation in response to flat slab subduction inboard of the aseismic Cocos Ridge, Osa Peninsula, Costa Rica. Lithosphere 5:247-264.

Gardner, T. W., D. Verdonck, N. M. Pinter, R. Singerland, K. P. Furlong, T. F. Bullard, and S. G. Wells. 1992. Quaternary uplift astride the aseismic Cocos Ridge, Pacific Coast, Costa Rica. GSA Bulletin 104:219-232.

Giaconia, F., G. Booth-Rea, J. M. Martínez-Martínez, J. M. Azañón, J. V. Pérez-Peña, J. Pérez-Romero, and I. Villegas. 2012. Geomorphic evidence of active tectonics in the Sierra Alhamilla (eastern Betics, SE Spain). Geomorphology 145146:90-106.

Goldblatt, C., M. W. Claire, T. M. Lenton, A. J. Matthews, A. J. Watson, and K. J. Zahnle. 2009. Nitrogen-enhanced greenhouse warming on early Earth. Nature Geoscience 2: 891-896.

Hall, S. J., and P. A. Matson. 2003. Nutrient status of tropical rain forests influences soil $\mathrm{N}$ dynamics after $\mathrm{N}$ additions. Ecological Monographs 73:107-129.

Handley, L. L., A. T. Austin, D. Robinson, C. M. Scrimgeour, J. A. Raven, T. H. E. Heaton, S. Schmidt, and G. R. Steward. 1999. The ${ }^{15} \mathrm{~N}$ natural abundance $\left(\delta^{15} \mathrm{~N}\right)$ of ecosystem samples reflects measures of water availability. Australian Journal of Plant Physiology 26:185-199.
Hart, S. C., J. M. Stark, E. A. Davidson, and M. K. Firestone. 1994. Nitrogen mineralization and immobilization. Pages 985-1018 in R. Weaver, editor. Methods of soil analysis, part 2: microbiological and biochemical properties. Soil Science Society of America, Madison, Wisconsin, USA.

Hedin, L. O., J. J. Armesto, and A. H. Johnson. 1995. Patterns of nutrient loss from unpolluted, old-growth temperate forests: evaluation of biogeochemical theory. Ecology 76: 493-509.

Hedin, L. O., E. N. J. Brookshire, D. N. L. Menge, and A. R. Barron. 2009. The nitrogen paradox in tropical forest ecosystems. Annual Review of Ecology, Evolution, and Systematics 40:613-635.

Hedin, L. O., P. M. Vitousek, and P. A. Matson. 2003. Nutrient losses over four million years of tropical forest development. Ecology 84:2231-2255.

Heimsath, A. M., W. E. Dietrich, K. Nishiizumi, and R. C. Finkel. 1997. The soil production function and landscape equilibrium. Nature 388:358-361.

Hilton, R. G., A. Galy, A. J. West, N. Hovius, and G. G. Roberts. 2013. Geomorphic control on the $\delta^{15} \mathrm{~N}$ of mountain forests. Biogeosciences 10:1693-1705.

Holloway, J. M., and R. A. Dahlgren. 2002. Nitrogen in rock: occurrences and biogeochemical implications. Global Biogeochemical Cycles 16(4):65-1-65-17.

Houlton, B. Z., and E. Bai. 2009. Imprint of denitrifying bacteria on the global terrestrial biosphere. Proceedings of the National Academy of Sciences USA 106:21713-21716.

Houlton, B. Z., D. M. Sigman, and L. O. Hedin. 2006. Isotopic evidence for large gaseous nitrogen losses from tropical rainforests. Proceedings of the National Academy of Sciences USA 103:8745-50.

Houlton, B. Z., Y. Wang, P. M. Vitousek, and C. B. Field. 2008. A unifying framework for dinitrogen fixation in the terrestrial biosphere. Nature 454:327-330.

Hovius, N., C. P. Stark, M. A. Tutton, and L. D. Abbott. 1998. Landslide-driven drainage network evolution in a pre-steadystate mountain belt: Finisterre Mountains, Papua New Guinea. Geology 26(12):1071-1074.

Jenny, H. 1941. Factors of soil formation: a system of quantitative pedology. McGraw-Hill, New York, New York, USA.

Johnsson, M. J., and R. F. Stallard. 1989. Physiographic controls on the composition of sediments derived from volcanic and sedimentary terrains on Barro Colorado Island, Panama. Journal of Sedimentary Petrology 59:768-781.

Kao, S., and K. Liu. 2000. Stable carbon and nitrogen isotope systematics in a human-disturbed watershed (Lanyang-Hsi) in Taiwan and the estimation of biogenic particulate organic carbon and nitrogen fluxes. Global Biogeochemical Cycles 14:189-198.

Kaspari, M., M. N. Garcia, K. E. Harms, M. Santana, S. J. Wright, and J. B. Yavitt. 2008. Multiple nutrients limit litterfall and decomposition in a tropical forest. Ecology Letters 11:35-43.

Kleber, M., L. Schwendenmann, E. Veldkamp, J. Rößner, and R. Jahn. 2007. Halloysite versus gibbsite: Silicon cycling as a pedogenetic process in two lowland neotropical rain forest soils of La Selva, Costa Rica. Geoderma 138:1-11.

Laurance, W. F., P. M. Fearnside, S. G. Laurance, P. Delamonica, T. E. Lovejoy, J. M. Rankin-de Merona, J. Q. Chambers, and C. Gascon. 1999. Relationship between soils and Amazon forest biomass: a landscape-scale study. Forest Ecology and Management 118:127-138.

Lohse, K. A., and W. E. Dietrich. 2005. Contrasting effects of soil development on hydrological properties and flow paths. Water Resources Research 41:W12419.

Luizao, R. C. C., F. J. Luizao, R. Q. Paiva, T. F. Monteiro, L. S. Sousa, and B. Kruijt. 2004. Variation of carbon and nitrogen 
cycling processes along a topographic gradient in a central Amazonian forest. Global Change Biology 10:592-600.

Martinelli, L. A., M. C. Piccolo, A. R. Townsend, P. M. Vitousek, E. Cuevas, W. McDowell, G. P. Robertson, O. C. Santos, and K. Treseder. 1999. Nitrogen stable isotopic composition of leaves and soil: tropical versus temperate forests. Biogeochemistry 46:45-65.

McLauchlan, K. K., J. J. Williams, J. M. Craine, and E. S. Jeffers. 2013. Changes in global nitrogen cycling during the Holocene epoch. Nature 495:352-355.

McSwiney, C. P., W. H. McDowell, and M. Keller. 2001. Distribution of nitrous oxide and regulators of its production across a tropical rainforest catena in the Luquillo Experimental Forest, Puerto Rico. Biogeochemistry 56:265-286.

Michaelides, K., D. Lister, J. Wainwright, and A. J. Parsons. 2012. Linking runoff and erosion dynamics to nutrient fluxes in a degrading dryland landscape. Journal of Geophysical Research 117:G00N15.

Morell, K. D., E. Kirby, D. M. Fisher, and M. van Soest. 2012. Geomorphic and exhumational response of the Central American Volcanic Arc to Cocos Ridge subduction. Journal of Geophysical Research 117:B04409.

Morford, S. L., B. Z. Houlton, and R. A. Dahlgren. 2011. Increased forest ecosystem carbon and nitrogen storage from nitrogen rich bedrock. Nature 477:78-81.

Murphy, S., and R. F. Stallard. 2012. Water quality and landscape processes of four watersheds in eastern Puerto Rico. Professional Paper 1979. U.S. Geological Survey, Reston, Virginia, USA.

Nardoto, G. B., J. P. H. B. Ometto, J. R. Ehleringer, N. Higuchi, M. M. da C. Bustamante, and L. A. Martinelli. 2008. Understanding the influences of spatial patterns on $\mathrm{N}$ availability within the Brazilian Amazon Forest. Ecosystems 11:1234-1246.

Nemani, R. R., C. D. Keeling, H. Hashimoto, W. M. Jolly, S. C. Piper, C. J. Tucker, R. B. Myneni, and S. W. Running. 2003. Climate-driven increases in global terrestrial net primary production from 1982 to 1999. Science 300:1560-1563.

Olff, H., J. Huisman, and B. F. Van Tooren. 1993. Species dynamics and nutrient accumulation during early primary succession in coastal sand dunes. Journal of Ecology 81:693706.

Pelletier, J. D. 2012. A spatially distributed model for the longterm suspended sediment discharge and delivery ratio of drainage basins. Journal of Geophysical Research 117: F02028.

Perakis, S. S., and L. O. Hedin. 2002. Nitrogen loss from unpolluted South American forests mainly via dissolved organic compounds. Nature 415:416-419.

Porder, S., G. P. Asner, and P. M. Vitousek. 2005. Ground based and remotely sensed nutrient availability across a tropical landscape. Proceedings of the National Academy of Sciences USA 102:10909-10912.

Porder, S., and G. E. Hilley. 2011. Linking chronosequences with the rest of the world: predicting soil phosphorus content in denuding landscapes. Biogeochemistry 102:153-166.

Porder, S., P. M. Vitousek, O. A. Chadwick, C. P. Chamberlain, and G. E. Hilley. 2007. Uplift, erosion, and phosphorus limitation in terrestrial ecosystems. Ecosystems 10:158-170.

R Development Core Team. 2011. R: a language and environment for statistical computing. R Foundation for Statistical Computing, Vienna, Austria.

Randerson, J. T., et al. 2009. Systematic assessment of terrestrial biogeochemistry in coupled climate-carbon models. Global Change Biology 15:2462-2484.

Reich, P. B., and J. Oleksyn. 2004. Global patterns of plant leaf $\mathrm{N}$ and $\mathrm{P}$ in relation to temperature and latitude. Proceedings of the National Academy of Sciences USA 101:11001-11006.
Roering, J. J., J. W. Kirchner, and W. E. Dietrich. 1999. Evidence for nonlinear, diffusive sediment transport on hillslopes and implications for landscape morphology. Water Resources Research 35:853-870.

Scatena, F. N., and A. E. Lugo. 1995. Geomorphology, disturbance and the soil and vegetation of two subtropical wet steepland watersheds of Puerto Rico. Geomorphology 13:199-213.

Shanley, J. B., W. H. McDowell, and R. F. Stallard. 2011. Long-term patterns and short-term dynamics of stream solutes and suspended sediment in a rapidly weathering tropical watershed. Water Resources Research 47:1-11.

Sperazza, M., J. N. Moore, and M. C. Hendrix. 2004. Highresolution particle size analysis of naturally occurring very fine-grained sediment through laser diffractometry. Journal of Sedimentary Research 74:736-743.

Stallard, R. F. 1988. Weathering and erosion in the humid tropics. Pages 225-246 in A. Lerman and M. Meybeck, editors. Physical and chemical weathering in geochemical cycles. Kluwer Academic Publishers, Dordrecht, Holland.

Stark, J. M., and M. K. Firestone. 1996. Kinetic characteristics of ammonium-oxidizer communities in a California oak woodland-annual grassland. Soil Biology and Biochemistry 28:1307-1317.

Stolar, D. B., S. D. Willett, and D. R. Montgomery. 2007. Characterization of topographic steady state in Taiwan. Earth and Planetary Science Letters 261:421-431.

Taylor, P. G., W. R. Wieder, S. R. Weintraub, S. Cohen, C. C. Cleveland, and A. R. Townsend. in press. Organic forms dominate hydrologic nitrogen loss from a lowland tropical watershed. Ecology.

Thomas, M. F. 1994. Geomorphology in the tropics: a study of weathering and denudation in low latitudes. John Wiley \& Sons, Chichester, UK.

Tiessen, H., P. Chacon, and E. Cuevas. 1994. Phosphorus and nitrogen status in soils and vegetation along a toposequence of dystrophic rainforests on the Upper Rio Negro. Oecologia 99:145-150.

Townsend, A. R., G. P. Asner, and C. C. Cleveland. 2008. The biogeochemical heterogeneity of tropical forests. Trends in Ecology \& Evolution 23:424-431.

Townsend, A. R., C. C. Cleveland, B. Z. Houlton, C. B. Alden, and J. W. C. White. 2011. Multi-element regulation of the tropical forest carbon cycle. Frontiers in Ecology and the Environment 9:9-17.

Townsend-Small, A., M. E. McClain, and J. A. Brandes. 2005. Contributions of carbon and nitrogen from the Andes Mountains to the Amazon River: evidence from an elevational gradient of soils, plants, and river material. Limnology and Oceanography 50:672-685.

Vitousek, P. M. 2004. Nutrient cycling and limitation: Hawai'i as a model system. Princeton University Press, Princeton, New Jersey, USA.

Vitousek, P., O. Chadwick, P. Matson, S. Allison, L. Derry, L. Kettley, A. Luers, E. Mecking, V. Monastra, and S. Porder. 2003. Erosion and the rejuvenation of weathering-derived nutrient supply in an old tropical landscape. Ecosystems 6: 762-772.

Vitousek, P. M., and H. Farrington. 1997. Nutrient limitation and soil development: experimental test of a biogeochemical theory. Biogeochemistry 37:63-75.

Vitousek, P. M., and P. A. Matson. 1988. Nitrogen transformations in a range of tropical forest soils. Soil Biology and Biochemistry 20:361-367.

Vitousek, P. M., and R. L. Sanford. 1986. Nutrient cycling in moist tropical forest. Annual Review of Ecology and Systematics 17:137-167.

Walker, T., and J. Syers. 1976. The fate of phosphorus during pedogenesis. Geoderma 15:1-19. 
Weber, A., W. Huber, A. Weissenhofer, N. Zamora, and G. Zimmermann. 2001. An introductory field guide to the flowering plants of the Golfo Dulce rainforests of Costa Rica. Biologiezentrum des OÖ Landesmuseums, Linz, Austria.

Wieder, W. R., C. C. Cleveland, and A. R. Townsend. 2011. Throughfall exclusion and leaf litter addition drive higher rates of soil nitrous oxide emissions from a lowland wet tropical forest. Global Change Biology 17(10):3195-3207.
Wright, S. J., et al. 2011. Potassium, phosphorus, or nitrogen limit root allocation, tree growth, or litter production in a lowland tropical forest. Ecology 92:1616-1625.

Zimmermann, A., T. Francke, and H. Elsenbeer. 2012. Forests and erosion: insights from a study of suspended-sediment dynamics in an overland flow-prone rainforest catchment. Journal of Hydrology 429:170-181.

Zuur, A., E. Ieno, N. Walker, A. Saveliev, and G. Smith. 2010. Mixed effects models and extensions in ecology with R. Springer, New York, New York, USA.

\section{Supplemental Material}

\section{Ecological Archives}

The Appendix is available online: http://dx.doi.org/10.1890/14-0834.1.sm 